\title{
Pertumbuhan Vegetatif Rumput Raja (Pennisetum purpureophoides) dengan Perlakuan Pupuk Anorganik dan Organik
}

\section{Vegetative Growth of King Grass (Pennisetum purpureophoides) with Inorganic and Organic Fertilizer Treatment}

\section{Sonria Aritonang, Sientje Daisy Rumetor*, Onesimus Yoku}

Program Studi Peternakan, Jurusan Peternakan, Fakultas Peternakan, Jl. Gunung Salju, Amban, Manokwari, Papua Barat, 98314

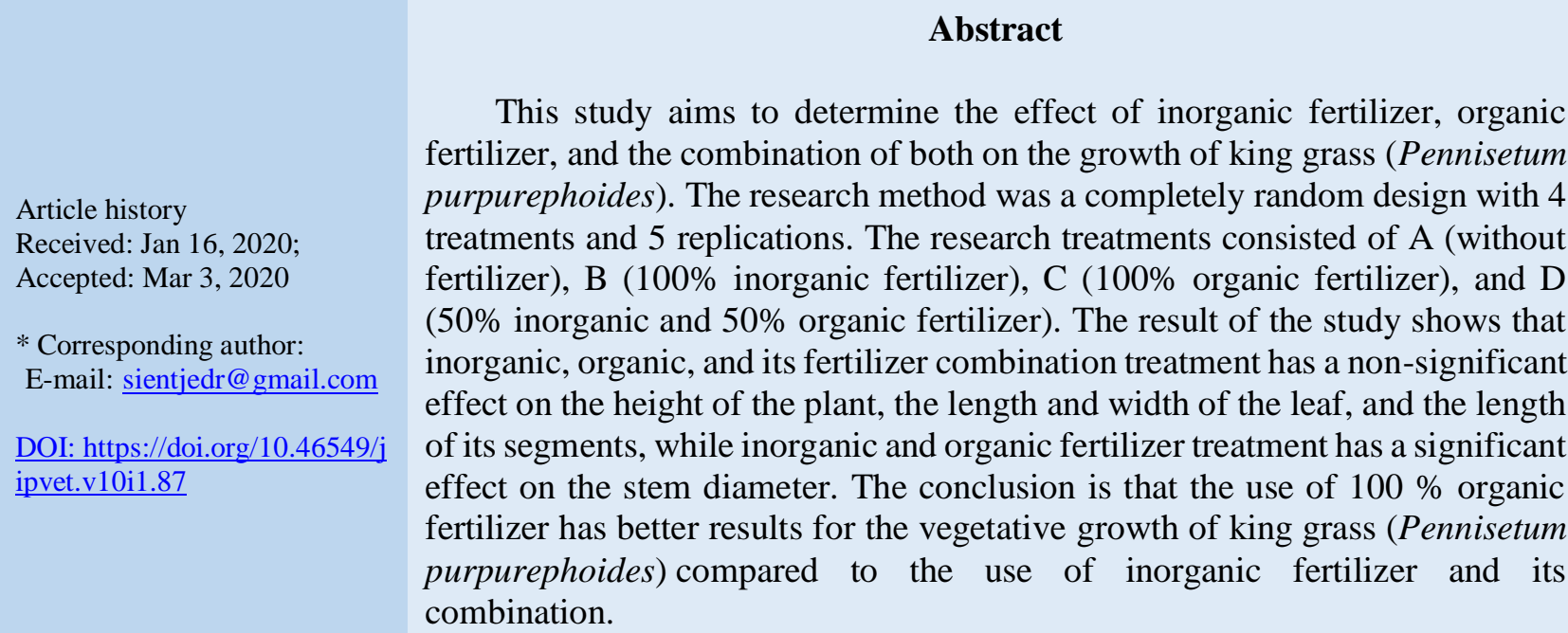

Keywords: King grass; Pennisetum Purpureophoide; Inorganic fertilizer; Organic fertilizer

\section{PENDAHULUAN}

Hijauan pakan merupakan makanan utama ternak ruminansia yang digunakan untuk berkembang biak dan berproduksi. Ketersedian hijauan pakan, baik kuantitas maupun kualitas yang masih rendah, menjadi kendala di Indonesia, sehingga mengakibatkan rendahnya produksi ternak khususnya, ternak ruminansia. Produktivitas ternak dapat ditingkatkan, apabila ketersedian hijauan pakan juga ditingkatkan.

Rumput raja (Pennisetum
purpureophoides) adalah salah satu hijauan unggul yang memiliki sifat produksi tinggi, kualitas baik dan daya adaptasi tinggi (Kushartono, 1997). Rumput ini tumbuh tegak berumpun-rumpun, ketinggian dapat mencapai kurang lebih $4 \mathrm{~m}$, batang tebal dan keras, daun lebar agak tegak, dan memiliki bulu pada helaian daun dekat liguna. Rumput ini juga baik ditanam di daerah yang subur di dataran rendah sampai dataran tinggi dan umumnya digunakan sebagai rumput potong (Suyitman $e t$ al ., 2003). Dalam rangka meningkatkan ketersediaan rumput raja perlu dilakukan penanaman. Keberhasilan penanaman hijauan pakan membutuhkan dukungan lingkungan dan fisik kimia tanah serta iklim yang ideal, pengolahan dan pemupukan tanah yang baik sehingga diharapkan dapat meningkatkan kualitas fisik dan kimia tanah yang baik pula.

Pemberian pupuk anorganik maupun organik secara langsung akan memperbaiki sifat fisik tanah dan sifat kimia tanah, yang pada akhirnya akan meningkatkan kualitas dari pertumbuhan rumput raja. Pertumbuhan tanaman merupakan penambahan ukuran yang tidak bisa kembali ke ukuran sebelumnya karena periode vegetatif terjadi pada perkembangan akar, batang dan daun (Agus, 2012).

Unsur nitrogen (N), fosfor (P), dan Kalium (K) merupakan unsur hara makro yang sangat diperlukan oleh tanaman. Menurut Rismunandar (1986) unsur hara yang paling 
dibutuhkan untuk pertumbuhan rumput raja adalah $\mathrm{N}$ sebagai pendorong pertumbuhan, menguatkan hijauan dan meningkatkan kadar protein serta pertumbuhan mikroorganisme yang penting bagi kesuburan tanaman. Demikian halnya menurut Pernata (2010) unsur hara yang paling dibutuhkan untuk pertumbuhan rumput tanaman adalah unsur $\mathrm{N}$ untuk pertumbuhan daun, batang, dan tunas tanaman, sedangkan unsur $\mathrm{P}$ untuk pembentukan akar, dan unsur $\mathrm{K}$ untuk pembentukan protein dan karbohidrat. Unsur hara ini diperoleh dari tanah sebagai media tumbuh atau dari pupuk. Menurut Agus (2012) pupuk digolongkan berdasarkan susunan kimianya menjadi pupuk organik dan anorganik. Pupuk organik atau kompos tersusun dari campuran limbah pertanian, limbah dapur, dan hasil sampingan pemeliharaan ternak (campuran feses, urine dan sisa pakan). Sedangkan pupuk anorganik tersusun dari satu atau gabungan beberapa komponen unsur kimia yang diproses melalui olahan pabrik.

Penggunaan pupuk anorganik secara terus menerus tanpa diimbangi dengan pemberian pupuk organik/kompos akan mengganggu sifat fisik tanah. Fisik tanah meliputi solum, tekstur, struktur, kadar air tanah, drainase dan porisitas tanah (Gardner et al ., 1991). Fisik tanah tersebut dapat mempengaruhi pertumbuhan dan produksi tanaman. Kondisi fisik tanah menentukan penerobosan akar didalam tanah, penyimpanan air, darainasi dan nutrisi tanaman.

Hijauan pakan seperti halnya tanaman lainnya, sangat memerlukan tanah yang subur, untuk keberhasilan pertumbuhan dan produksinya. Areal Taman Ternak Amban cukup baik sebagai areal pengembangan hijauan pakan. Namun karena tingginya intensitas penggunaan lahan, menyebabkan kondisi lahan di area tersebut cenderung menurun kesuburannnya. Upaya untuk meningkatkan kesuburan tanah dapat dilakukan dengan menambahkan pupuk anorganik dan/atau organik.

Anwar et al., (2000), mendapatkan produksi rumput raja, tanpa pemupukan sebesar $1,64 \mathrm{~kg} / \mathrm{m}^{2}$, menghasilkan tinggi tanaman (163 $\mathrm{cm})$, diameter batang $(1,35 \mathrm{~cm})$ dan panjang daun $(92,58 \mathrm{~cm})$ sedangkan dengan pemberian pupuk Urea $100 \mathrm{~kg} / \mathrm{ha}$ meningkat menjadi 2,20 $\mathrm{kg} / \mathrm{m}^{2}$, tinggi tanaman $(203 \mathrm{~cm})$, diameter batang $(1,64 \mathrm{~cm})$ dan panjang daun $(104,16 \mathrm{~cm})$ dan pemberian pupuk kandang 10 ton/ha meningkat menjadi $4,08 \mathrm{~kg} / \mathrm{m}^{2}$, tinggi tanaman $(256,5 \mathrm{~cm})$, diameter batang $(1,75 \mathrm{~cm})$ dan panjang daun $(120,61 \mathrm{~cm})$. selanjutnya penelitian yang dilakukan oleh Kushartono (2001) dengan pemberian pupuk kandang 10 ton/ha meningkat menjadi $3,26 \mathrm{~kg} / \mathrm{m}^{2}$, tinggi tanaman $(234 \mathrm{~cm})$, diameter batang $(1,81 \mathrm{~cm})$ dan panjang daun $(116,9 \mathrm{~cm})$. Berdasarkan hasil penelitian tersebut belum didapatkan rekomendasi yang pasti untuk pemupukan rumput raja, baik menggunakan pupuk organik maupun anorganik. Namun demikian sebagai spesies rumput hasil persilangan antara rumput gajah (Pennisetum purpureum) dengan rumput jamrawut mutiara (Pennisetum typhoides) maka penggunaan dosis pupuk rumput gajah memungkinkan untuk dicobakan.

Hasil penelitian Seseray dab Santoso, (2013), mendapatkan produksi rumput gajah, tanpa pemupukan sebesar $2,21 \mathrm{~kg} / \mathrm{m}^{2}$, sedangkan dengan pemberian pupuk NPK 50\% meningkat menjadi $2,87 \mathrm{~kg} / \mathrm{m}^{2}$ dan pemberian pupuk NPK $100 \%$ menurun menjadi 2,84 $\mathrm{kg} / \mathrm{m}^{2}$. selanjutnya penelitian yang dilakukan oleh Surajat et al., (2016) dengan pemberian pupuk bokashi (kotoran ayam) dengan dosis tanpa pupuk menghasilkan tinggi tanaman $(99,1062 \mathrm{~cm})$, diameter batang $(0,97 \mathrm{~cm})$ dan jumlah daun (10,97 helai), sedangkan dengan dosis 10 ton/ha menghasilkan tinggi tanaman $(132,4479 \mathrm{~cm})$, diameter batang $(1,43 \mathrm{~cm})$ dan jumlah daun (19,89 helai) dan dosis 15 ton/ha menghasilkan tinggi tanaman $(133,6146 \mathrm{~cm})$, diameter batang $(1,47 \mathrm{~cm})$ dan jumlah daun (21,77 helai), serta dosis 20 ton/ha menghasilkan tinggi tanaman $(129,9479 \mathrm{~cm})$, diameter batang $(1,36 \mathrm{~cm})$ dan jumlah daun (22,56 helai). Demikian halnya Yafur (2018) mendapatkan bahwa penggunaan $25 \%$ top kompos dalam media tanam legum Indigofera zollingeriana memberikan pengaruh yang segnifikan terhadap panjang daun $(24,7111 \mathrm{~cm})$ lebar daun $(1,90176 \mathrm{~cm})$ dan rasio batang $(3,0305 \mathrm{~cm}) .50 \%$ top kompos dalam media tanam legum Idigofera zollingeriana memberikan pengaruh yang segnifikan terhadap panjang daun $(18,1389 \mathrm{~cm})$ lebar daun $(1,72345 \mathrm{~cm})$ dan rasio batang $(3,6375 \mathrm{~cm})$. Sejauh ini belum diperoleh informasi ratio 
pupuk anorganik dan organic untuk pertumbuhan vegetatif rumput raja (Pennisetum purpureophoides) yang baik, sehingga perlu dilakukan penelitian.

Penelitian ini bertujuan untuk mengetahui sejauh mana pertumbuhan vegetatif rumput raja (Pennisetum purpureophoides) dengan perlakuan pupuk pupuk anorganik dan organik.

\section{MATERI DAN METODE}

Penelitian ini dilaksanakan di Taman Ternak Fakultas Peternakan Universitas Papua Manokwari. Penelitian dilaksanakan pada tanggal 9 Juni sampai 9 Oktober 2018.

Bahan dan Alat

Bahan yang digunakan dalam penelitian ini adalah 20 pols rumput raja, $100 \mathrm{~kg}$ tanah, kertas label, polibag ukuran 30 x $30 \mathrm{~cm}$ kapasitas $5 \mathrm{~kg}$, air, dan 112,6 g pupuk organik (top kompos), 11,4 g pupuk anorganik (NPK 16:16:16) perhitungan dosis pemukukan dapat dilihat pada Lampiran 2. Alat yang digunakan terdiri dari cangkul, parang, gunting stek ukuran 15 $\mathrm{cm}$, pita ukur, sekop, ayakan tanah ukuran $0,5 \mathrm{x}$ $0,5 \mathrm{~mm}$, terpal, timbangan analitik kapasitas $250 \mathrm{~g}$, timbangan digital kapasitas $5 \mathrm{~kg}$ dan gayung kapasitas $240 \mathrm{ml}$, ember, jangka sorong, laptop dan alat tulis menulis.

\section{RANCANGAN YANG DIGUNAKAN}

Penelitian ini menggunakan Rancangan Acak Lengkap (RAL), dengan 4 perlakuan dan 5 ulangan sehingga diperoleh 20 satuan percobaan. Perlakuan yang diberikan terdiri dari:

$\begin{array}{ll}\text { A } & : \text { Tanpa pupuk } \\ \text { B } & : 100 \% \text { Pupuk Anorganik } \\ \text { C } & : 100 \% \text { Pupuk Organik } \\ \text { D } & : 50 \% \text { Pupuk Anorganik dan } 50 \% \\ & \text { Pupuk Organik } \\ \text { PERSIAPAN MEDIA TANAH }\end{array}$

Tanah yang digunakan dari lokasi taman ternak yang sebelumnya digemburkan kemudian diletakkan diatas terpal dan dikeringkan. Selanjutnya diayak menggunakan ayakan $0,5 \times 0,5 \mathrm{~mm}$. Tanah akan digunakan sebagai media disiapkan sebayak $100 \mathrm{~kg}$.

\section{PEMILIHAN BIBIT}

Bibit rumput raja yang akan digunakan adalah pols rumpun yang yang paling muda, tegap, besar, dan sehat sehat berdasarkan rekomendasi Lugiyo et al., (2000). Pols yang digunakan sebagai bibit rumput raja diambil dari Balai Pembibitan Ternak dan Hijauan Makanan Ternak (BPT-HMT) SP 5 Kampung Macuan Distrik Masni Kabupaten Manokwari.

\section{PEMBERIAN PUPUK}

Jumlah pupuk yang akan digunakan untuk perlakuan B sebayak 1,44 g/polibag, C (15,03 g/polibag) dan D (0,72 pupuk anorganik dan 7,51 pupuk organik). Sebelum pupuk dicampur dengan tanah, hal yang pertama dilakukan adalah menimbang pupuk dengan timbangan analitik sesuai dosis pupuk yang telah ditentukan. Selanjutnya tanah ditimbang dengan timbangan digital sebanyak 5 $\mathrm{kg} /$ polibag. Pada perlakuan A tanah langsung dimasukkan kedalam polibag yang telah diberi label. Sedangkan tanah dan pupuk pada perlakuan B ulangan 1 sampai perlakuan D ulangan 5, masing-masing dicampur hingga homogen. Setelah homogen, tanah yang telah dicampur pupuk langsung dimasukkan pada masing-masing polibag yang telah diberi label. Pemberian pupuk ini dilakukan hanya satu kali selama penelitian berlangsung.

Tahap selanjutnya adalah pengacakan yang dilakukan menggunakan angka acak (random) dalam buku rancangan percobaan. Hasil pengacakan ditempatkan pada areal penelitian dengan jarak antar polibag $90 \mathrm{~cm}$.

\section{PENANAMAN BIBIT}

Bibit pols selanjutnya ditanam yang ditanam adalah pols dan didalam satu pols terdapat dua batang rumput raja. Setiap polibag terdapat satu pols dan bibit yang dibutuhkan adalah 20 pols. Untuk penyulaman dibutuhkan 2 bibit untuk setiap perlakuan. Jarak polibag satu ke polibag yang lain yaitu $90 \mathrm{~cm}$.

PEMELIHARAAN TANAMAN

Pemeliharaan tanaman meliputi penyiraman dan pembersihan gulma. Penyiraman dilakukan setiap hari yaitu pada sore hari. Tanaman disiram dengan menggunakan gayung. Penyiraman tidak dilakukan pada saat turun hujan tetapi ditambah menjadi 2 kali pada saat temperatur meningkat. Sedangkan untuk pembersihan gulma yang tumbuh di lahan penelitian dibersihkan 1 kali seminggu. 


\section{PENGUKURAN}

Pengukuran variabel pertumbuhan vegetatif dimulai setelah terbentuk dua daun rumput raja (Pennisetum purpureophoides) yang sempurna dan pengukuran berakhir setelah rumput berumur 3 bulan. Pengukuran tinggi tanaman setiap minggu sedangkan variabel yang lain diukur setelah panen.

\section{VARIABEL YANG DIAMATI}

Variabel yang diamati dalam penelitian ini terdiri dari:

\section{TINGGI TANAMAN (CM)}

Tinggi tanaman diukur dengan pita ukur dari permukaan tanah sampai dengan ujung daun tertinggi.

\section{PANJANG DAUN (CM)}

Panjang daun diukur setelah rumput dipotong dengan gunting stek. Kemudian dalam satu rumpun dipilih 3 batang untuk dilakukan pengukuran. Pengukuran dilakukan dari ujung pangkal daun hingga ujung daun dengan menggunakan pita ukur.

\section{LEBAR DAUN (CM)}

Lebar daun diukur setelah rumput dipotong dengan gunting stek. Kemudian dalam satu rumpun dipilih 3 batang untuk dilakukan pengukuran. Lebar daun diukur setelah dipilih daun yang paling lebar dalam 1 pols, serta pengukuran dengan menggunakan pita ukur.

\section{PANJANG RUAS (CM)}

Panjang ruas diukur setelah rumput dipotong dengan gunting stek. Kemudian dalam satu rumpun dipilih 3 batang untuk dilakukan pengukuran. Panjang ruas diukur dari ruas satu keruas berikutnya dan diukur dengan pita ukur

\section{DIAMETER BATANG (CM)}

Diameter batang diukur pada bagian tengah batang (berdasarkan rekomendasi Surajat et al ., 2016) menggunakan jangka sorong. Pengukuran dilakukan pada 3 batang tanaman untuk dilakukan peengukuran.

\section{ANALISIS DATA}

Data yang diperoleh dianalisis menggunakan aplikasi MINITAB Versi.17, apabila hasil menunjukkan pengaruh yang nyata $(\mathrm{P}<0.05)$ atau sangat nyata $(\mathrm{P}<0.01)$ dilanjutkan dengan uji Tukey.

\section{HASIL DAN PEMBAHASAN}

Hasil penelitian terhadap pertumbuhan vegetatif rumput raja (Pennisetum purpureophoides) dengan perlakuan pupuk organik dan pupuk anorganik dapat dilihat pada Tabel 1.

Secara keseluruhan terlihat ada perubahan yang terjadi pada pertumbuhan vegetatif rumput raja (Pennisetum purpureophoides). Masing-masing variabel pertumbuhan vegetatif dibahas sebagai berikut :

\section{TINGGI TANAMAN}

Tabel 1 memperlihatkan rata-rata tinggi tanaman rumput raja tertinggi diperoleh pada perlakuan C (100\% pupuk organik) dan terendah Perlakuan D (kombinasi pupuk anoranik dan pupuk organik).

Hasil analisis ragam menunjukkan bahwa perlakuan tidak berpengaruh nyata $(\mathrm{P}>0,05)$ terhadap tinggi tanaman rumput raja $(P$. purpureophoides). Hal ini menunjukkan bahwa pupuk belum memberikan respon terhadap pertumbuhan vegetatif (tinggi tanaman) rumput raja . Kondisi ini dapat terjadi karena pemberian pupuk masih dibawah rekomendasi dari penggunaan pupuk untuk rumput raja.

Penggunaan pupuk anorganik $0,058 \mathrm{~kg} / \mathrm{m} 2$ masih dibawah rekomendasi Anwar et al., (2000) sebesar $0,01 \mathrm{~kg} / \mathrm{m} 2$ dan penggunaan pupuk organik $0,6 \mathrm{~kg} / \mathrm{m} 2$ masih dibawah rekomendasi Kushartono (2001) sebesar 1 $\mathrm{kg} / \mathrm{m} 2$. Namun demikian tinggi tanaman rumput raja hasil penelitian ini dengan menggunakan pupuk anorganik $(254,12 \mathrm{~cm})$ masih lebih tinggi dibanding rekomendasi Anwar et al., (2000) sebesar $163 \mathrm{~cm}$ dan rekomendasi Kushartono (2001) sebesar 205 $\mathrm{cm}$ untuk penggunaan dosis pupuk pupuk yang lebih tinggi. Demikian halnya tinggi tanaman rumput raja yang menggunakan pupuk organik $(260,38 \mathrm{~cm})$ masih lebih tinggi dibanding rekomendasi Anwar et al., (2000) sebesar 256,5 cm dan rekomendasi Kushartono (2001) sebesar $234 \mathrm{~cm}$ untuk penggunaan dosis pupuk organik yang lebih tinggi. Pada penggunaan kombinasi pupuk anorganik dan pupuk organik tinggi tanaman rumput raja mencapai $228 \mathrm{~cm}$ yang lebih baik dibandingkan dengan hasil penelitian Hendarto (2005) sebesar 174,34 cm dengan dosis penggunaan kombinasi pupuk anorganik dan pupuk organik yang lebih tinggi. 
Tabel 1. Rata-rata tinggi tanaman, panjang daun, lebar daun, panjang ruas, dan diameter batang rumput raja

\begin{tabular}{|c|c|c|c|c|c|}
\hline \multirow{2}{*}{ Variabel } & \multicolumn{4}{|c|}{ Perlakuan } & \multirow{2}{*}{$\mathbf{P}$} \\
\hline & $\mathbf{A}$ & B & C & D & \\
\hline Tinggi tanaman $(\mathrm{cm})$ & 235,26 & 254,12 & 260,38 & 228,54 & 0,205 \\
\hline Panjang Daun (cm) & 155,05 & 132,19 & 135,23 & 132,21 & 0,138 \\
\hline Lebar Daun (cm) & 4,80 & 4,68 & 4,63 & 4,96 & 0,227 \\
\hline Panjang Ruas (cm) & 8,62 & 7,70 & 8,99 & 7,89 & 0,581 \\
\hline Diameter Batang $(\mathrm{cm})$ & $2,08^{a b}$ & $1,57^{\mathrm{a}}$ & $2,22^{\mathrm{b}}$ & $1,96^{\mathrm{ab}}$ & 0,022 \\
\hline
\end{tabular}

Keterangan: A (tanpa pupuk), B (100\% pupuk anorganik), C (100\% pupuk organik), dan D (50\% pupuk organik dan pupuk anorganik). Superskrip yang sama kearah baris menunjukkan perbedaan nyata

Jika dilihat dari laju pertumbuhan rumput raja (Gambar 1), maka terjadi pola pertumbuhan sigmoid. Gardner, et al., (1991) mengemukakan bahwa pertumbuhan cepat kemudian melambat sampai tercapai laju pertumbuhan yang maksimum. Perlakuan tanpa pupuk, $100 \%$ pupuk organik, dan kombinasi pupuk organik dan anorganik menunjukkan laju pertumbuhan yang relatif sama, sedangkan perlakuan $100 \%$ anorganik menunjukkan karakteristik pertumbuhan dengan pola yang berbeda atau pertumbuhan sigmoid belum tercapai. Pupuk organik yang memiliki sifat ketersidiaan ketersediaan unsur hara lambat, hara yang berasal dari bahan organik diperlukan untuk diubah dari bentuk ikatan konfleks organik yang tidak dapat dimanfaatkan oleh tanaman menjadi bentuk senyawa organik dan anorganik sederhana yang dapat diserap oleh tanaman (Jooetono, 1995). Pada minggu ke 9 terjadi pertumbuhan tanaman rumput raja yang baik atau mencapai puncak pertumbuhan. Anwar et al, (2000) menyatakan bahwa pertumbuhan rumput raja dicapai pada umur 9 minggui adalah waktu terbaik untuk pengukuran tinggi tanaman, lebar daun dan diameter batang.

\section{PANIANG DAUN}

Tabel 1 memperlihatkan rata-rata panjang daun rumput raja dengan terpanjang pada perlakuan A (tanpa pupuk) dan terendah pada perlakuan B (100\% pupuk organik).

Hasil analisis ragam menunjukkan bahwa perlakuan tidak berpengaruh nyata $(\mathrm{P}>0,05)$ terhadap panjang daun tanaman rumput raja $(\mathrm{P}$. purpureophoides). Hal ini menunjukkan bahwa pupuk belum memberikan respon terhadap pertumbuhan vegetatif (panjang daun) rumput raja, yang menandakan ketersediaan unsur hara untuk belum terserap baik oleh tanaman dalam memenuhi kebutuhan pertambahan panjang daun. Namun demikian panjang daun rumput raja hasil penelitian ini dengan menggunakan pupuk anorganik $(132,19 \mathrm{~cm})$ masih lebih panjang dibanding Anwar et al., (2000) sebesar 104,16 cm dan Kushartono (2001) sebesar $102,3 \mathrm{~cm}$ untuk penggunaan dosis pupuk pupuk yang lebih tinggi. Demikian halnya panjang daun rumput raja yang menggunakan pupuk organik $(135,23 \mathrm{~cm})$ masih lebih panjang dibanding Anwar et al., (2000) sebesar 120,61 cm dan Kushartono (2001) sebesar 116,9 cm untuk penggunaan dosis pupuk organik yang lebih tinggi.

\section{LEBAR DAUN}

Tabel 1 memperlihatkan rata-rata lebar daun rumput raja terlebar pada (perlakuan D, kombinasi pupuk anorganik dan organik) dan terendah pada perlakuan C (100\% pupuk organik) dapat dilihat pada Tabel 1.

Hasil analisis ragam menunjukkan bahwa perlakuan tidak berpengaruh nyata $(\mathrm{P}>0,05)$ terhadap lebar daun tanaman rumput raja (P. purpureophoides). Hal ini menunjukkan bahwa pupuk belum memberikan respon terhadap pertumbuhan vegetatif rumput raja atau tanaman belum mampu memanfaatkan secara optimal unsur hara tersedia Namun demikian lebar daun rumput raja hasil penelitian ini dengan menggunakan pupuk anorganik (4,68 $\mathrm{cm})$ masih lebih lebar dibanding Anwar et al., (2000) sebesar 3,48 cm dan Kushartono (2001) sebesar 3,25 cm untuk penggunaan dosis pupuk pupuk yang lebih tinggi. Demikian halnya lebar daun rumput raja yang menggunakan pupuk organik $(4,63 \mathrm{~cm})$ masih lebih panjang 
dibanding Anwar et al., (2000) sebesar 3,93 cm dan Kushartono (2001) sebesar 4,03 cm untuk penggunaan dosis pupuk organik yang lebih tinggi. Pemberian kombinasi pupuk organik dan anorganik menghasilkan tingkat pertumbuhan yang baik. Hendarto (2005) menjelaskan adanya unsur Nitrogen, Fosfor, dan Kalium dalam pupuk organik serta penambahan NPK dari pupuk anorganik yang digunakan secara terpadu menghasilkan kerja sama guna meningkatkan guna pertumbuhan yang baik, diantaranya lebar daun tanaman rumput raja.

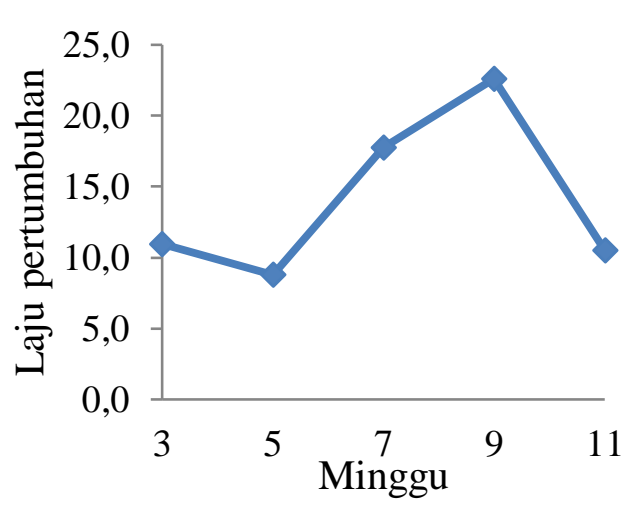

Pupuk Organik

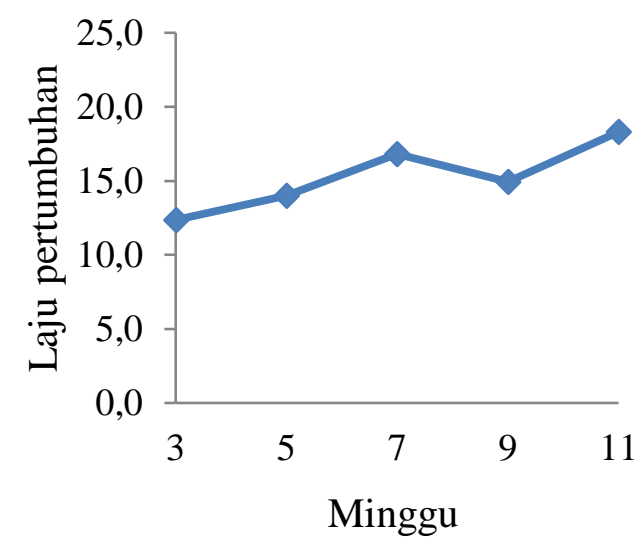

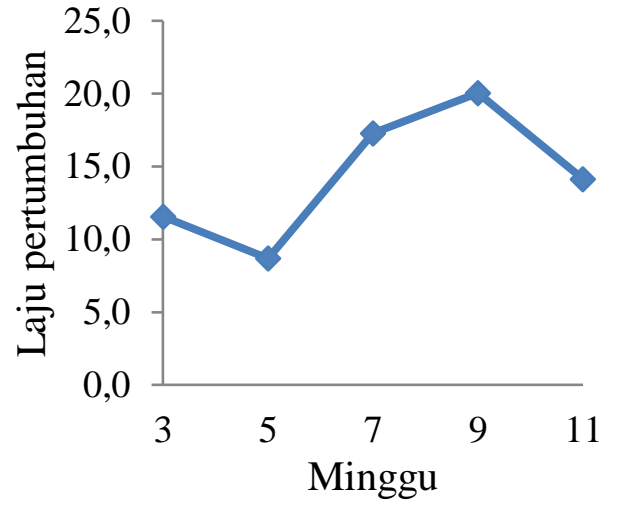

Kombinasi Organik dan Anorganik

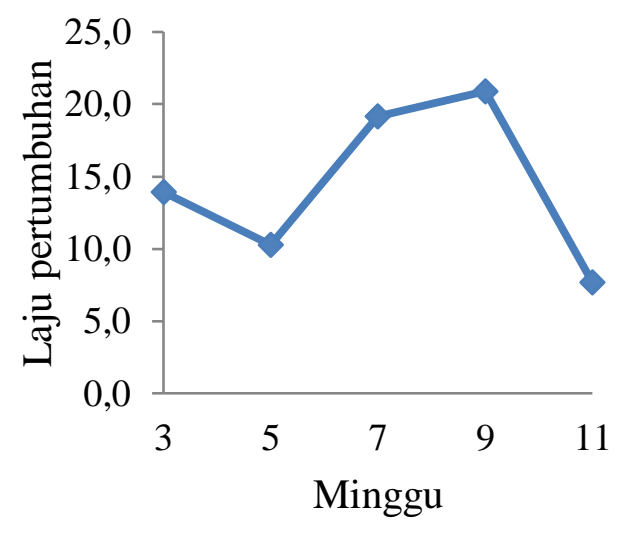

Gambar 1. Laju pertumbuhan $(\mathrm{cm})$ rumput raja dengan penggunaan pupuk organik dan anorganik

\section{PANJANG RUAS}

Tabel 1 memperlihatkan rata-rata panjang ruas rumput raja terpanjang pada perlakuan $\mathrm{C}$ (100\% pupuk organik) dan terendah pada perlakuan B (100\% pupuk anorganik) dapat dilihat pada Tabel 1.

Hasil analisis ragam menunjukkan bahwa perlakuan tidak berpengaruh nyata $(\mathrm{P}>0,05)$ terhadap panjang ruas tanaman rumput raja $(\mathrm{P}$. purpureophoides). Hal ini menunjukkan bahwa dengan memberikan pupuk atau tidak diberikan pupuk panjang ruas tidak terjadi perubahan, karena dipengaruhi oleh genetik tanaman atau karakteristik tanaman. Hal ini sesuai dengan pernyataan Gardner et al., (1991) bahwa pola ruas yang panjang dan pendek merupakan karakteristik spesies tanaman. Pupuk organik dapat menambah unsur hara ke dalam tanah, dapat mempertinggi humus, memperbaiki struktur tanah dan mendorong kehidupan jasad renik tanah sehingga dapat meningkatkan pertumbuhan tanaman (Suriadikarta et al., 2006).

\section{DIAMETER BATANG}

Hasil analisis ragam menunjukkan bahwa perlakuan berpengaruh nyata $(\mathrm{P}<0,05)$ terhadap diameter batang rumput raja (P. purpurephoides). hasil uji lanjut Tukey, mendapatkan bahwa perlakuan tanpa pupuk menghasilkan diameter batang yang tidak berbeda nyata $(\mathrm{P}>0,05)$ dengan perlakuan pupuk organik, pupuk anorganik dan kombinasi pupuk organik dan pupuk anorganik. Demikian halnya perlakuan pupuk anorganik menghasilkan diameter batang rumput raja yang tidak berbeda nyata $(\mathrm{P}>0,05)$ dengan perlakuaan kombinasi. Hal yang sama juga 
terlihat pada diameter batang rumput raja dari perlakuan pupuk organik tidak berbeda nyata dengan diameter batang kombinasi pupuk organik dan pupuk anorganik. Sedangkan diameter batang rumput raja dari perlakuan pupuk organik berbeda nyata $(\mathrm{P}<0,05)$ lebih besar dibandingkan pupuk anorganik. Hal ini menunjukkan bahwa unsur hara atau pemupukan yang diberikan belum bisa mengoptimalkan pertumbuhan tanaman, karena unsur hara lebih fokus dalam pembesaran batang dan perbanyakan jumlah anakan. Hal ini sesuai dengan pernyataan Gardner et al., (1991) sebagian besar unsur hara yang diperlukan tanaman diserap dari tanah melalui akar dan dilanjutkan pada batang.

Dalam penelitian ini penggunaan pupuk anorganik $0,58 \mathrm{~kg} / \mathrm{m} 2$ masih dibawah rekomendasi Anwar et al., (2000) sebesar 0,01 $\mathrm{kg} / \mathrm{m} 2$ dan penggunaan pupuk organik 0,6 $\mathrm{kg} / \mathrm{m} 2$ masih dibawah rekomendasi Kushartono (2001) sebesar $1 \mathrm{~kg} / \mathrm{m} 2$. Namun demikian diameter batang rumput raja hasil penelitian ini dengan menggunakan pupuk anorganik $(1,57$ $\mathrm{cm})$ masih lebih rendah dibanding Anwar et al., (2000) sebesar 1,64 cm dan Kushartono (2001) sebesar 1,68 cm untuk penggunaan dosis pupuk pupuk yang lebih tinggi. Namun lain halnya diameter batang rumput raja yang menggunakan pupuk organik $(2,22 \mathrm{~cm})$ masih lebih tinggi dibanding Anwar et al., (2000) sebesar 1,75 cm dan Kushartono (2001) sebesar $1,81 \mathrm{~cm}$ untuk penggunaan dosis pupuk organik yang lebih tinggi.

Pada penggunaan kombinasi pupuk anorganik dan pupuk organik tinggi tanaman rumput raja mencapai $1,96 \mathrm{~cm}$ yang lebih baik dibandingkan dengan hasil penelitian Hendarto dan Suwarno (2013) sebesar 1,5 cm dengan dosis penggunaan kombinasi pupuk anorganik dan organik yang lebih tinggi

Atmojo (2003) menyatakan untuk membantu ketersedian hara dengan kebutuhan hara oleh tanaman dapat dilakukan dengan penambahan pupuk organik. Pupuk organik dapat menambah unsur hara ke dalam tanah, dapat mempertinggi humus, memperbaiki struktur tanah dan mendorong kehidupan jasad renik tanah sehingga dapat meningkatkan pertumbuhan tanaman (Suriadikarta et al., 2006). Selanjutnya Suntoro (2003) menyatakan bahwa pupuk organik dapat menggemburkan tanah, menjadi media hidup sejumlah bakteri dan dalam jangka panjang memperbaiki sifat fisik tanah.

\section{KESIMPULAN}

Berdasarkan hasil penelitian ini dapat disimpulkan bahwa pertumbuhan vegetatif terbaik rumput raja didapat dari penggunaan pupuk organik yang dilihat dari tinggi tanaman $(260,38 \mathrm{~cm})$, panjang daun $(135,23 \mathrm{~cm})$, lebar daun $(4,63 \mathrm{~cm})$, panjang ruas $(8,99 \mathrm{~cm})$ dan diameter batang $(2,22 \mathrm{~cm})$

\section{DAFTAR PUSTAKA}

Agus, C, Dr. 2012. Pengolahan Bahan Organik Peran dalam Kehidupan dan Lingkungan. BPFE Yogyakarta: Yogyakarta.

Anwar, M dan Kushartono, B. 2000. Pengaruh perbedaan penggunaan pupuk terhadap produksi rumput raja (Pennisetum purpurephoides) di lapangan percobaan Ciawi. Temu Teknis Fungsional Non Peneliti. Bogor.

Atmojo, S, W. 2003. Peranan Bahan Organik Terhadap Kesuburan Tanah dan Upaya Pengolahannya. Skripsi. Fakultas Pertanian. Universitas Sebelas Maret : Surakarta.

Gardner, P. F, R, B. Pearce, R. L. Mitchel.L. 1991. Fisiologi Tanaman Budidaya. Universitas Indonesia (UI-Press). Jakarta.

Hendarto, E. 2005. Pengaruh kombinasi dan taraf urea terhadap kualitas visual dan produksi rumput raja (Pennisetum purpureophoides). Jurnal Pembangunan Pedesaan Vol. V No. (2).

Hendarto, E dan Suwarno. 2013. Pengaruh kombinasi antara pupuk kandang urea pada tampilan aspek pertumbuhan tanaman rumput raja pada pemanenan defoliasi ke empat. Jurnal Ilmu-ilmu Hayati dan Fisik. Vol 15 (2).

Jooetono. 1995. Biologi dan Biokimia Peruraian Bahan Organik Tanah. Faperta UGM. Yogyakarta.

Kushartono, B. 2001. Pengaruh curah hujan dan pola pemupukan terhadap produksi rumput raja (Pennisetum purpureophoides). Temu Teknis Fungsional Non Peneliti. Bogor. 
Kushartono, S. 1997. Teknik penanaman rumput raja (king grass) berdasarkan prinsip penanaman tebu. Lokakarya Fungsional Non Peneliti. Bogor.

Lugiyo dan Sumarto. 2000. Teknik budidaya rumput gajah cv hawaii (Pennisetum purpureum). Temu Teknis Fungsional Non Penelitian.

Pernata, S. A. 2010. Meningkatkan Hasil Panen dengan Pupuk Organik. Jakarta: PT Agromedia Pustaka.

Rismunandar. 1986. Mengenal Tanaman Buahbuahan. Sinar baru: Bandung.

Seseray, D, Y. dan Santoso, B. (2013). Produksi rumput gajah (Pennisetum purpureum) yang diberi pupuk $\mathrm{N}, \mathrm{P}$ dan $\mathrm{K}$ dengan dosis 0,50 dan $100 \%$ pada devoliasi hari ke-45. Sains Peternakan: Jurnal Penelitian Ilmu Peternakan, 2013, 11.1: 49-55.

Suntoro, W, A. 2003. Peranan bahan organik terhadap kesuburan tanah dan upaya pengelolaannya. Pidato Pengukuhan Guru
Besar. Program Pascasarjana, Universitas Sebelas Maret. Surakarta.

Surajat, A, Natsir, S dan La, M. 2016. Respon pertumbuhan rumput gajah (Pennisetum purpureum Var. Hawai) yang diberi pupuk bokashi kotoran ayam broiler dengan dosis yang berbeda. JITRO. Vol 3(3).

Suriadikarta, D. A. dan Simanukkalit R, D, M. 2006. Pupuk Organik dan Pupuk Hayati. Balai Besar Penelitian dan Pengembangan Sumberdaya Lahan Pertanian. Bogor.

Suyitman, S. Jalaludin, Abudinar, N. Muis, Ifradi, N. Jamaran, M. Peto, dan Tanamasni. 2003. Agrostologi. Fakultas Peternakan Universitas Andalas, Padang.

Yafur, F. N. 2018. Pengaruh Suhu Rendaman dan Media Tumbuh Terhadap Daya Kecambah Benih dan Pertumbuhan Tanaman (Indigofera zollingeriana). Tesis. Program Pasca Sarjana. Universitas Papua, Manokwari. 